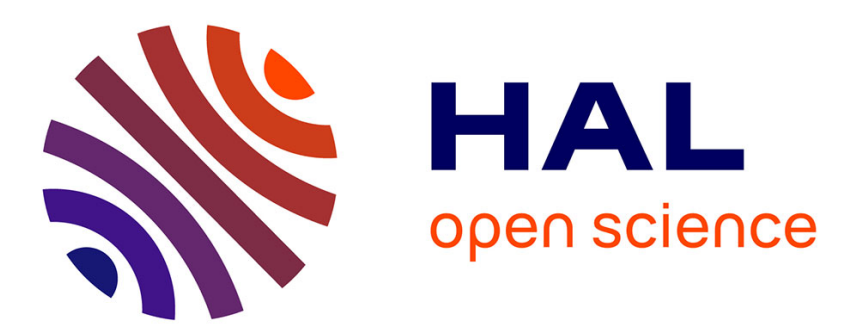

\title{
The Psychoanalytical Method and the Disaster of Totalitarianism: Borderline States as the Psychical Equivalent of the Discontent in Civilization?
}

François Villa

\section{- To cite this version:}

François Villa. The Psychoanalytical Method and the Disaster of Totalitarianism: Borderline States as the Psychical Equivalent of the Discontent in Civilization?. Critical Inquiry, 2014, 40 (6), pp.267 287. 10.1086/674115 . hal-01494568

\section{HAL Id: hal-01494568 \\ https://hal.science/hal-01494568}

Submitted on 23 Mar 2017

HAL is a multi-disciplinary open access archive for the deposit and dissemination of scientific research documents, whether they are published or not. The documents may come from teaching and research institutions in France or abroad, or from public or private research centers.
L'archive ouverte pluridisciplinaire HAL, est destinée au dépôt et à la diffusion de documents scientifiques de niveau recherche, publiés ou non, émanant des établissements d'enseignement et de recherche français ou étrangers, des laboratoires publics ou privés. 


\section{The Psychoanalytical Method and the Disaster of Totalitarianism: Borderline States as the Psychical Equivalent of the Discontent in Civilization?}

François Villa

We are not only in possession of [our freedom] but have the urge to defend it. ${ }^{1}$

This essay would like firstly to return to the concept of the discontent in civilization in order to discuss the disaster of totalitarianism and secondly to look at the connections between this discontent and disaster and borderline personality disorders.

In Civilization and Its Discontents, Sigmund Freud quotes from one of Johann Wolfgang von Goethe's Ballads ("little children do not like it") to refer to the "the inborn human inclination to 'badness', to aggressiveness and destructiveness, and so to cruelty as well." ${ }^{2}$ Although this inclination is indisputably something we find very difficult to admit and think about, the disaster of totalitarian regimes, which blend together technological progress with barbarism, forces us to do so. We have not yet fully understood these tragedies and the very real feelings of disillusionment and disappointment they have provoked-yes, humans really are capable of thatleaving behind a layer of despair at the very core of our civilization as a kind of signature.

Unless otherwise noted, all translations are my own.

1. Étienne de la Boetie, The Discourse of Voluntary Servitude, in de la Boetie and Paul Bonnefon, The Politics of Obedience and Étienne de la Boetie, trans. Harry Kurz (Montreal, 2007), p. 120.

2. Sigmund Freud, Civilization and Its Discontents (1930), The Standard Edition of the Complete Psychological Works of Sigmund Freud, trans. and ed. James Strachey, 24 vols.

(London, 1953-74), 21:119.

Critical Inquiry 40 (Winter 2014)

(C) 2014 by The University of Chicago. 0093-1896/14/4002-0011\$10.00. All rights reserved. 
From the large majority of psychoanalytic literature, one may easily get the impression that the cultural catastrophe that occurred in the middle of the twentieth century has had no substantial effect on either the theory or practice of psychoanalysis. We are facing a paradox: a disaster took place on the Old Continent, which undermined the very foundations of humanity, its unity and modes of coexistence, yet supposedly it has made no changes to the psychical determinants of individuation and of community building. This paradox further presumes that the constitutive elements of psychic life constitute an indestructible and immutable core able to resist both the passing of time and the events of human life, that these elements are invariable, atemporal, and ahistorical.

We of course cannot exclude this possibility; however, it seems equally impossible to argue that the disaster has simply left no trace at all in our bodies, and when I say bodies I am naturally referring to the inextricable interweaving of the psyche and the soma. I believe that we are far from having fully accounted for the effects that the individual and collective experience of totalitarianism has had on our present. It seems evident that, both individually and collectively, we are still left with the task of putting this catastrophe, which brought on a radical loss of meaning and perhaps sowed seeds of despair in the deepest layers of our minds, into words. Despite the substantial amount of research and thinking that has been carried out, it seems to me that those who try to speak about what happened easily provoke suspicion in others, but also in themselves. Within the psychoanalytic community, this suspicion generally takes the form of "that is not a psychoanalytic matter."

And, indeed, what relation could there be between this disaster and psychoanalysis? Do psychoanalysts have anything relevant to say about what happened? Is this not a dimension outside our field? These are the questions I would like to tackle in this essay.

I will start by returning to my previous question, that is, whether we can indeed believe that we may go on with the psychoanalytic task as if the wave of terror and barbarism that irrupted into our civilization had not also shaken the walls of the analyst's office. Are we not forgetting that one of the goals of totalitarianism was, precisely, to undo the separation be-

FRANÇOIS VILLA is a practicing psychoanalyst and a member of the Association Psychanalytique de France and the International Psychoanalytic Association. He is also professor and associate chair of the Department of Psychopathology, Paris Diderot University at Sorbonne Paris Cité and the Center for Research in Psychoanalysis, Medicine, and Society Lab. His email is villa@univ-paris-diderot.fr 
tween the public and the private, between the crowd as a willing serf and its Führer? ${ }^{2}$ One could object that this confidence rests on the fact that the indestructible psychic core remains unchangeable and that, as analysts, we essentially only deal with the psyche's constitutive elements, which are largely invariant, atemporal, and ahistorical. However, is it possible that our idea of the unchangeable psychic core is in reality, too, only a belief, an illusion made possible by an operation of splitting? Its advantage would be to let us pretend as if there was nothing to be heard about this disaster in psychoanalytic treatment, as if none of it was making itself heard.

If this were true, we would have to ask ourselves if any major disaster has really occurred and to consider that there was nothing unprecedented or extraordinary about its particular forms of barbarism, that it was only a repetition, one of the many cruel tragedies of human history-a sound and fury that did not reach the foundations of either our being or our coexistence. If, on the other hand, we think that a disaster did, in fact, occur, we cannot exclude that its devastating effects have spread as far as the depths of the human psyche and have even undermined individual modes of belonging to the human race.

To exclude this second possibility, to my mind, would be equal to not recognizing the extent to which our field is linked to the progress of civilization. In Freud's view, psychoanalysis was in fact one of the determining factors of this progress and was itself determined, in terms of both its creation and its development, by the scientific Weltanschauung. ${ }^{4}$ Psychoanalytic treatment and the work of culture (Kulturarbeit) specific to it are contributions to our civilization, strengthening the individual's capacity to positively or negatively appropriate the reasons and prohibitions on which a society relies. No progress can be made in either psychoanalytic theory or individual treatments unless there is a certain coherence with the advances or impasses of civilization itself. As Nathalie Zaltzman has argued, the expression work of culture refers to an intimate knotting-together of being and culture, of the individual and the collective; the rise and fall of either one will necessarily be a source of conflict for the other. ${ }^{5}$

3. See Charlotte Beradt, the Third Reich of Dreams, the Nightmares of a Nation 1933-1939, trans. Adriane Gottwald (New York, 1968), p. 149. Also see François Villa, "Au cœur du rêve, la horde," Penser/Rêver 15 (Spring 2009): 41-60. The Führer may of course refer to Adolf Hitler or Joseph Stalin, but also and especially to Freud's description of the figure of the leader in Freud, "Group Psychology and the Analysis of the Ego" (1921), The Standard Edition of the Complete Psychological Works of Sigmund Freud, 18:65-144.

4. See Freud, New Introductory Lectures On Psycho-Analysis (1933), The Standard Edition of the Complete Psychological Works of Sigmund Freud, 22:157-82; hereafter abbreviated N.

5. See Nathalie Zaltzman, De la guérison psychanalytique (Paris, 1998) and L'Esprit du mal (Paris, 2007). 
The First World War showed us that "human creations are easily destroyed, and science and technology, which have built them up, can also be used for their annihilation." ${ }^{6}$ The lesson of totalitarian regimes is even more cruel because we now know (but without actually knowing it) that in the concentration camps, which reveal the essence of these regimes, we see, as Robert Antelme puts it, "those things that men ought not to have seen, things that could not be put into words," and, as a consequence, "we maintain a kind of stupor that can't be translated into any deed." sufficiently considered the possibility that the psychic processes engendered by what was seen, since they are far from having become fully conscious, may have turned into intense and persistent memories, which resist remembering and instead continue to haunt both the individual and the collective? ${ }^{8}$ In such a case, would these "new" traces not become as indestructible as their older counterparts?

We are unable to assess the extent to which totalitarian regimes transform minds and mentalities, but neither do we know to what degree our own minds and ways of thinking are the direct product of this transformation. Was this change only an ephemeral, transitory one? Should we outright reject the idea of an irreversible transformation as well as the hypothesis that the regression that encouraged the rise of the Nazi regime and at the same time was made possible by it ultimately brought back something that had never existed before? If this idea seems too extreme, let us at least ask what happened to cultural ideals after the catastrophe has dismantled and disrupted both the project of civilization and psychical personality.

One could criticize me for not succeeding completely in distinguishing between the individual and the collective. I cannot reject this criticism completely, but I would argue that the tendency to conflate them might to some extent have to do, precisely, with the effect of the disaster on our thought. One of the characteristics of totalitarianism is to negate the singularity of the individual, to reduce him, as Theodor Adorno writes, to a mere specimen. The result is the coalescence between the individual and the collective, which precipitates the emergence of the totalitarian mass. This reduction, which destroys subjectivity, demonstrates the close inter-

\footnotetext{
6. Freud, "The Future of an Illusion" (1927), The Standard Edition of the Complete Psychological Works of Sigmund Freud, 21:5.

7. Robert Antelme, "Revenge?" (1945), in On Robert Antelme's "The Human Race": Essays and Commentary, trans. Jeffrey Haight, ed. Daniel Dobbels (Evanston, Ill., 2003), p. 12.

8. See Freud, Beyond the Pleasure Principle (1920), The Standard Edition of the Complete Psychological Works of Sigmund Freud, 18:20.

9. See Zaltzman's discussion of William Golding's Lord of the Flies in Zaltzman, L'Esprit du mal.
} 
dependence between the individual's construction and formation and forms of social organization. One of the challenges of overcoming the still-active effects of the disaster would then be to find a path of individuation that is different from the type of individualism focused narrowly on self-preservation..$^{10}$ In trying to understand this individualism, it is no doubt useful for us to think about it as a possible effect of the desolation of totalitarianism-as its current residue. Freud opens the discussion about the intimate connections between the individual and the collective in Group Psychology and the Analysis of the Ego, but the movement from one to the other still remains unclear to us. ${ }^{11}$

In my previous work, I asked whether totalitarian discourse might have intensified a desire (Sehnsucht) already present in the psyche, one that, by echoing this discourse, simultaneously contributed to its rise and triumph. ${ }^{12}$ Here, I would like to think about the possible changes that the living reappearance of the primal horde introduced into the psyche, as well as their various legacies. To do so, I will follow the example of Freud's 1915 essay "Thoughts for the Times on War and Death." ${ }^{13}$ Trying to understand the events of his time, Freud identified two distinct effects of the Great War: disillusionment with the progress of civilization and a change in our attitude towards death. To examine today's repercussions of the totalitarian tragedy, I will focus on the same two questions. Does the notion of disillusionment capture the shock suffered by humanity and civilization? And what happened to our approach to dying when the perpetrators of mass murders tried to erase their traces by a secondary elimination, of the bodies themselves?

At the end of his 1915 text "On Transience," Freud asks if all the objects and ideals that proved unable to resist the war and protect us from its train of hardships have definitely been lost and devalued. He answers that mourning these losses will, too, come to an end: "We shall build up again," he writes, "all that war has destroyed, and perhaps on firmer ground and more lastingly than before." 14

We only have our thought to understand this catastrophe, but our disillusionment concerns precisely our ability to confront, through thought, our inclination towards evil. Already before 1914 there were doubts

10. See Theodor W. Adorno, Negative Dialectics, trans. E. B. Ashton (London, 1973), p. 261.

11. See also Violence d'état et psychanalyse, ed. Janine Puget (Paris, 2001), and Maren and Marcelo Viñar, Exil et torture (Paris, 1989).

12. See Villa, "Au cœur du rêve, la horde," pp. 41-6o.

13. See Freud, “Thoughts for the Times on War and Death" (1915), The Standard Edition of the Complete Psychological Works of Sigmund Freud, 14:273-300.

14. Freud, "On Transience" (1916), The Standard Edition of the Complete Psychological Works of Sigmund Freud, 14:307. 
whether thought could actually face the brutal reality of the human drives and of the world itself, and the Great War confirmed and strengthened a number of considerations coming from the field of psychopathology. These observations led Freud to theorize a "queer" drive that is "directed to the destruction of its own organic home"- the death drive ( $N$, 22:105-6). Its hypothesis means that we cannot ignore the excessive nature of the drive's demands or the fact that its fundamental hostility to all efforts at its taming can turn into a passion of annihilation-of oneself, but also, by a deflection, of the other or, if that is impossible, again of oneself.

Beyond the Pleasure Principle invites us to think of life as being ruled by a predisposition to annihilation. It requires us to consider the role played by the death drive in the process of thought. Here, Freud returns, perhaps without realizing it, to a hypothesis he already put forward in the 1895 "Project for a Scientific Psychology": thought is not an end in itself, but it is primarily aimed at reestablishing the identity of perception, which could lead to a discharge and, as a consequence, to the extinction of the drive and of thought itself. ${ }^{15}$

In the Freudian conception, thought is an instrument of the death drive and of destruction, as well as of Eros and construction. It is not easy to admit that not only do the tendencies and goals of the death drive act and express themselves in thought but that in fact they are also thought's own goals and tendencies. Like the death drive, thought aims at the dissolution of all organization; it tries to undo all of the connections that it itself helped to create and that are essential to life. It too is inherently striving, blindly and quietly, towards a return to that former state with an "inorganic face," as Laurence Kahn puts it, ${ }^{16}$ of life decomposed into its most elementary particles, of death stripped of any dimension of consolation and reduced to its biological inevitability.

The power of Eros alone forces the death drive to defer the arrival of death and to tolerate the digression of life in order to reach its goal. However, it is only to destroy the many assemblies and schemes Eros can create that the death drive temporarily becomes intertwined with the life drives. In fact, it only contributes to the work of Eros in order to eventually be able to undo it. And only this entanglement lessens its self-destructive force, by redirecting its aggression outside, towards libidinal objects. This diversion enables thought to acquire new functions.

Eros forces thought to take part in the search for the prehistorical ob-

15. See Freud, "Project for a Scientific Psychology" (1950 [1895]), The Standard Edition of the Complete Psychological Works of Sigmund Freud, 1:360.

16. Laurence Kahn, Faire parler le destin (Paris, 2005), p. 211; hereafter abbreviated F. 
ject: the aim of desire and the first aspiration of psychical life. When perception fails to establish an identity between the lost object and the current object of inner or outer reality, it is thought's duty to try and find out if some of the perceived difference could be ignored and the present object could match its nostalgia-provoking predecessor. Thought therefore essentially serves the pleasure principle. However, necessity will impose a change, thus establishing the reality principle, which will then try to consider, despite unpleasure, the perceived differences and to admit their real existence. On the one hand, thought is therefore ready to use a resemblance to forge an illusion that satisfies desire and to act as if this illusion were true. On the other hand, it confronts the truth of the absence of the desired object and of the expected satisfaction, and it allows us to act, free from illusion, upon reality seen as it is. We see that there is a thin line between thought's tendency to give in to illusion and the human acquisition of freedom to think and act even when the world turns out to disappoint us. This interplay enables the subject to scale back the violence of the drive and gives birth to scientific thought, assigning it the task of forcing us to see the reality that exists outside, independently of us-including the reality that provokes unpleasure-and to establish a certain correlation between the fields of thought and action. Freud designates this as the capacity to perceive reality as truth and even as the love of truth.

Before the Great War, civilization seemed to have made an irreversible series of advances; this hope was shared by many highly cultivated people, including Freud, who wished to believe that scientific and cultural progress went hand in hand. This optimism was slightly diminished by the paradoxical revelation that the progress of scientific knowledge simultaneously induced a loss of meaning in the world. The conjunction of this loss of meaning and a decline of consolatory religious belief engendered a kind of vague apprehension about the future, which Max Weber called "the 'disenchantment of the world"' ${ }_{17}$ and which fuelled both individual and social anxiety.

Freud connected this loss of meaning to the fact that scientific thought, still very young, knew too little, while many people remained under the spell of religious conceptions. However, he argued, this was only a transitional stage, and in time the scientific spirit would assert itself, and reason would accept the reality of the human condition. We find a trace of this struggle against disenchantment in "Psychical (or Mental) Treatment." Science, Freud says, has dismissed the magical power of words too quickly,

17. Max Weber, "Science as a Vocation," From Max Weber: Essays in Sociology, trans. and ed. H. H. Gerth and C. Wright Mills (New York, 1946), p. 16. 
mistaking it for simply a remainder of religiosity.$^{18}$ Psychoanalysis is then a long detour by which science is reminded, from within its own field, of the double necessity of restoring to words a part of their former magical power and of paying attention to the strange disposition to belief proper to human beings. Thinking about the future of the enlightened Man, who too often turns out to be, as Freud thought, a cultural hypocrite living beyond his psychical means, ${ }^{19}$ we must look at both of these dimensions. In fact, how could we think about the effects of discourse on the constitution of a group and about the effects of propaganda unless we first take this magical power of words and the disposition to belief into account?

The principle of reality introduces a movement into thought, thus expanding the field of perception of reality, while also leading to a loss of illusion. The significance of this opening up cannot be overemphasized. The reality principle opposes Eros only because by obeying the law of pleasure alone we would be led to the realization of the death drive, that is, to self-destruction. By destroying illusions, the reality principle destabilizes us and shows us to what extent the world remains foreign to us, a source of dissatisfaction and aggression that calls for our aggression in return. In addition to the path towards more scientific knowledge, there are also some others, such as the path of a certain melancholization of existence, but also that of a permanent war against the world and one's fellows. By making us face reality, the reality principle also enables a certain deflection of the drives towards the external world. This digression is a real protection; nonetheless, it can turn out to be a deadly one.

Thought's initial goal was to suppress its own reasons for existence, and this still remains true; we think in order to get rid of the painful excitement that was thought's original stimulus. This excitement is the ceaseless activity of the drives striving for satisfaction, which at the same time means their extinction. To the ego, this radical goal represents the final extreme, the worst possible scenario; yet it can sometimes, strangely and brutally, choose this end voluntarily-either when it feels abandoned by the world and decides to abandon itself or when, having substituted the ego ideal with the overvalued object, it is ready to dissolve itself in it, to preserve it by becoming one with it.

We could therefore say that thought emerges precisely from where the death drive has failed. Its first purpose is to compensate for this failure; it develops because it is unable to become the drive's efficient accomplice. In

18. See Freud, "Psychical (or Mental) Treatment" (1905), The Standard Edition of the Complete Psychological Works of Sigmund Freud, 7:283.

19. See Freud, "Thoughts for the Times on War and Death," 14:284. 
despair, thought enters into its first complications in order to serve its primary master as quickly as possible. Yet by doing this, it moves from the regime of immediacy to the regime of deferral; it discovers the logic of temporization and temporality. It is now able to wait, and also it starts to believe in the power of waiting. The emergence of confident expectation is no doubt contemporaneous with the first failure of thought. We find it even in the greatest distress-its probable origin. It remains active here and leads the human being, full of hope, to believe that there must indeed be someone or something he can trust, a hope that the contingencies of human life can strengthen as well as disappoint. When disappointment does occur, it brings with it another of our familiar guests: anxious expectation. It is no surprise that, in addition to hope, expectation can equally well contain anxiety or even anguish and that it may be filled with a nostalgic desire just as well as with hatred towards all that stands in its way.

Expectation tends to converge on an object of belief, to which the human being can become compulsively attached. Expectation, overcoming indifference, is now determined exclusively by the object that has cast its shadow over the human subject. The ego can sometimes become the site of a hateful passion towards all that contests the chosen object's supremacy. When serving their ideals, human beings can easily behave in the most irrational ways and with a naivety and submissiveness quite beyond belief.

Thought, which was originally meant to disappear as soon as its original task had been accomplished, now becomes more durable, and its attention, driven by confident expectation, turns to both the inner and the outer world, looking for objects that satisfy the principle of constancy as well as for materials that may assist the death drive. While remaining subject to the death drive, it now becomes involved in the process of becoming initiated by the drive's failure. The conflict between the two drives continues to tear it apart. On the one hand, it tries to satisfy the needs of life by responding to its various emergencies, and by doing so it still aims at its own abolishment. Yet, on the other hand, its logic has now changed; it has started to reason, even to became reasonable, and supporting the digression of life has become its second reason for existence. As Pierre Fédida puts it, thought should have facilitated a return to the inanimate state, but instead it must now be content with only slightly disanimating the cauldron of the drives, with desexualizing life enough to make it livable. ${ }^{20}$ The guardians of life are thus also the servants of death.

Although he knows all this, Freud has great confidence in thought. In

20. See Pierre Fédida, Des bienfaits de la depression: Éloge de la psychothérapie (Paris, 2001). 
$1910,{ }^{21} 1927^{22}$ and $1933,{ }^{23}$ he argues that the return of truth clearly does not immediately lead to its admission, but its force is such that, in due time, even "the harshest truths are heard and recognized at last, after the interests they have injured and the emotions they have roused have exhausted their fury." ${ }^{24}$

Without regard for the truth, we only wish to see of the real what satisfies our desire. What we call reality is most often a neoreality we substitute for it. Any psychic organization entails a loss of reality; ${ }^{25}$ however, illusions contain not only primitive beliefs but also the truth concealed by them. Truth can be heard upon the lifting or weakening of repression; paradoxically, this process is facilitated by the death drive. By attacking the work of Eros, the death drive again frees thought for indeterminate expectation, thus setting it in motion. Unbridled by illusion, thought can then open the way for the return of the repressed and give truth its chance.

The return of the repressed is a necessary albeit insufficient condition; it does not do away with the work that is needed for truth, once it has been perceived, to be recognized. Without this psychic effort, the return will lead to regression rather than progress. In the latter case, priority will again be given to the mechanism of projection, in the form of individual or collective acts. The return of truth exposes human insignificance in the vastness of the universe, as well as reason's feebleness vis-à-vis the forces of the drive; the ability to bear these painful truths is what could make human beings truly irreligious.

21. See Freud, "The Future Prospects of Psycho-Analytic Therapy" (1910), The Standard

Edition of the Complete Psychological Works of Sigmund Freud, 11:139-51.

22.

We may insist as often as we like that man's intellect is powerless in comparison with his instinctual life, and we may be right in this. Nevertheless, there is something peculiar about this weakness. The voice of the intellect is a soft one, but it does not rest till it has gained a hearing. Finally, after a countless succession of rebuffs, it succeeds. This is one of the few points on which one may be optimistic about the future of mankind, but it is in itself a point of no small importance. [Freud, "The Future of an Illusion," 21:53]

23.

Our best hope for the future is that intellect—-the scientific spirit, reason-may in process of time establish a dictatorship in the mental life of man. The nature of reason is a guarantee that afterwards it will not fail to give man's emotional impulses and what is determined by them the position they deserve. But the common compulsion exercised by such a dominance of reason will prove to be the strongest uniting bond among men and lead the way to further unions. Whatever, like religion's prohibition against thought, opposes such a development, is a danger for the future of mankind. [ $N, 22: 171-72]$

24. Freud, "The Future Prospects of Psycho-Analytic Therapy," 11:146.

25. See Freud, "The Loss of Reality in Neurosis and Psychosis" (1924), The Standard Edition of the Complete Psychological Works of Sigmund Freud, 19:181-87. 
The argument of an inherently violent human nature was enough to undermine Freud's belief in reason and provoke a moment of desolation, which he overcomes in his 1933 essay "Why War?" by turning to a quasiDarwinian hypothesis. The process of cultural evolution takes place over such a long time that its effects could be compared to the domestication of animals. It engenders a series of bodily modifications and psychic transformations. Certain displacements of the aims of the drive, required by this civilizing process, will then be transformed into inherent biological compulsions, which can be transmitted to future generations. Originally, we only think in order to change the world so that it best corresponds to our desires, and it is true that what happens in and to thought has social and cultural effects. Shouldn't we therefore imagine that the world could change us in return?

Moving from the individual to the collective, the relationship to reality and the approach to the demands of the drive are both sites of their mutual discord. Culture commands the psychic apparatus to tolerate a certain amount of unpleasure, although the latter's main function is to avoid unpleasure, and in trying to defend itself from painful feelings it is able to sacrifice not just truth but many other things as well. The survival of civilization requires that the individual's right to violence must be restricted, while the survival of the individual dictates that aggression must be able to find an outlet in the outside world. As Freud writes in 1933, "it really seems as though it is necessary for us to destroy some other thing or person ... in order to guard against the impulsion to self-destruction" ( $N, 21: 105)$. We are not only driven towards others because of our need for love but also because we need to destroy-including destroying other human beings-in order to survive. This is the source of our hostility towards all the institutions used by culture to defend itself against individual autocracy and gives credence to the idea of war as practically unavoidable. However, it is another paradox that by giving the death drive an external outlet, hostility simultaneously contributes to the work of self-preservation carried out by Eros.

War shows us that cultural requirements are, to a much larger degree, ideals imposed by the superego rather than psychically elaborated tenets of personal ethics. Nations and the states that represent them only need to slightly relax these requirements, by moving from peace to war, for individuals to reveal themselves for what they really are: not quite as cultivated as we thought and essentially dependent on and addicted to hegemonic ideas and leaders. ${ }^{26}$ The Great War showed the persistence of the primal dimension in human beings and led Freud to argue that the lust for killing

26. See Freud, “Thoughts for the Times on War and Death,” 14:279. 
in our blood comes from the endless series of generations of murderers, from whom we are descended. ${ }^{27}$ It also powerfully attests to the fact that a level of psychic organization we had considered to be forever lost remains part of our psychic reality and under certain conditions can regain its former dominance in this day and age. Freud adds that, on the other hand, it may also happen that a developmental stage abandoned for regression cannot again be attained and reinstated; therefore it is not true that everything within the psyche is indestructible.

Even before the rise of totalitarian regimes, the relation between the psyche and culture was difficult. However, it becomes much more so once we have travelled beyond the pleasure principle into a world where the death drive leads the dance of life and where the gap between individual and cultural development has deepened even further.

Freud himself is confounded by his hypothesis of the death drive. Sometimes he shares his difficulties with it or with being convinced of it. ${ }^{28}$ At other times, he remembers his own resistance to the idea of a destructive drive when it first emerged in 1912. And sometimes he is surprised that he could have "overlooked the ubiquity of non-erotic aggressivity and destructiveness and can have failed to give it its due place in our interpretation of life." ${ }^{29}$ The fact is, he admits, that it is indeed difficult to accept the improbable hypothesis that destruction is part and parcel of the human makeup and to make destruction the driving force of change. Such belief not only goes against the idealized image of the human being but also compels us to think about the discord within the individual himself, within the collective, and between the two of them. Yet "unfortunately," Freud writes, "what history tells us and what we ourselves have experienced ... rather justifies a judgment that belief in the 'goodness' of human nature is one of those evil illusions [that] in reality ... only cause damage" ( $N$, 22:104).

In order to support his hypothesis, Freud appeals to history and his own experience, but soon enough he corrects himself and says that it is primarily on the basis of clinical considerations that he has "argued in favour of a special aggressive and destructive instinct in men not on account of the teachings of history or of our experience in life" ( $N$, 22:104). Perhaps he is too quick in dismissing history-including the Great War and his own life

27. See ibid., 14:296.

28. "It may be asked whether and how far I am myself convinced of the truth of the hypotheses that have been set out in these pages. My answer would be that I am not convinced myself. ... Or, more precisely, that I do not know how far I believe in them" (Freud, Beyond the Pleasure Principle, 18:58).

29. Freud, Civilization and Its Discontents, p. 119. 
experience-to make psychoanalytic experience his only reference. We only need to remember the crucial place of neurosis in the architecture of Beyond the Pleasure Principle.

Isn't this one of those denials that show how obscure the genesis and genealogy of our modes of thinking remain to us? Forgetting has always already beaten us. Isn't this an expression of a quick backing off, which we can easily relate to? Perhaps we too are overhasty in dismissing history and our personal experience. Dismissing it too quickly because we stick to the individual realm, we do not have to face the enigma of the inextricable links between the individual and the collective.

Freud is writing during an age that certainly had its share of disillusionment and disenchantment, but he was still far from conceiving of or imagining that evil could triumph over the world. It did not yet know the demonic resources of an enthusiastic crowd gathered around its Führer. Therefore it did not yet have to overcome, as Hannah Arendt writes, our real resistance to imagining that "evil-doing in our time has a morbid force of attraction." ${ }^{30}$ What we saw next was the enactment of this attraction.

I count myself among those who are not discouraged by the improbability of the hypothesis of the death drive and who even consider it essential to our understanding of the shock human beings suffered in the totalitarian disaster. ${ }^{31}$ However, becoming familiar with this drive, admitting to its existence and fully accepting its power in our daily lives is indeed highly disagreeable.

For Freud, the First World War, like all other wars, forced us to again start believing in death, due to the daily accumulation of killings. Thought could no longer reduce death from a necessity to a chance event. Although the resulting disillusionment was severe, it did not make human beings fear that they no longer belonged to humankind. The following war was quite a different matter. It was not an ordinary war. The logic of the Nazi regime dictated victory or death; at the time of the defeat, there were thus no enemies in the traditional sense of the word to sign the peace agreement. On the one hand there was the victorious side and, on the other, enemies of humanity, who felt neither responsible for nor guilty of the crimes they had committed. The Nazis had been defeated, but was this

30. F. Borkenau, The Totalitarian Enemy (London, 1940), p. 231; quoted in Hannah Arendt, The Origins of Totalitarianism, (San Diego, 1985), p. 301.

31. Among those not discouraged by the apparent improbability of the death drive are the already cited Nathalie Zaltzman and Laurence Kahn; I should also add André Green and Pierre Fédida. See André Green, "Pourquoi le mal?” Nouvelle Revue de Psychanalyse 38 (Autumn 1988): 239-61 and Pourquoi les pulsions de destruction ou de mort? (Paris, 2007); and Fédida et al., Humain / déshumain (Paris, 2007). 
enough to eradicate the poison instilled in everyone's psyche? Had the evil that had struck humankind from the inside definitely been defeated?32

This war was not just another repetition forcing us to believe in death. Tragically, it forced us to fear something, as Adorno wrote, far worse than death ${ }^{33}$ - not so much because of the still greater accumulation of deaths, but because of the mass disappearances, with the destruction of the bodies of the exterminated. More than an accumulation of deaths, the Second World War created an accumulation of disappearances.

During the previous war, technological progress considerably increased the means of killing at a distance. In spite of this, death still essentially involved a face-to-face encounter, where dying had to be confronted when looking into the other's face. According to Adorno, what made death bearable before the age of totalitarianism was the idea of its epic unity with a full life. ${ }^{34}$ As Laurence Kahn points out, we were still operating within the Freudian logic employed in Totem and Taboo of a "murder being part of the fateful finality of the brothers' pact [that creates] the social contract. [This murder] is still organized by an epic story [which] when it is narrated, represses hatred in favor of nostalgia and prohibition" (F, p. 228).

With Beyond the Pleasure Principle, the death of the inorganic life that the death drive continues to strive for is no longer the death caused by a murder; it is at best a death that results from the "murder" of the self caused by the impossibility of mastering the drive. Death is no longer something that one causes or suffers, but what one carries within oneself and which in turn, since it cannot arrive immediately, carries life forward. It is a death of internal causes, an impersonal death, stemming from our inability to dispose of our own waste. It has nothing to do with the intellectual questions death raises for an individual, due to ambivalence, who is standing by the dead body of a loved one or an acquaintance. The death of a murder has a human face; the death of the death drive is a shapeless, inanimate, and faceless mass.

The "politics" of the concentration camp expresses the totalitarian regime's will to erase both death and the dead; it goes hand in hand with the intention of not simply banning thought but making it downright impossible. These regimes only have one line of thought as their primary principle: that of the Führer. With such a master, both truth and the thought that could accept it are forbidden. Those who wish to continue thinking

32. See Villa and Eva Weil, review of The Spirit of Evil by Zaltzman, International Journal of Psychoanalysis 91 (2010): 667-74.

33. See Adorno, Minima Moralia: Reflections on a Damaged Life, trans. E. F. N. Jephcott (London, 2006), p. 38.

34. See Adorno, Negative Dialectics, p. 369. 
are the enemies. The ideal subject of the totalitarian regime is a desperate human being, ruled by cynicism and credulity.

Humans have come very far since the primitive age when, as Freud would have it, the living substance constantly re-created itself and died easily. ${ }^{35}$ Death has long ceased to be an easy matter. When millions are being massacred by an impersonal administrative machine, death no longer seems to have any place in the course of human life. Adorno argues that the fact that those who are killed and die are no longer human beings but mere specimens necessarily has an effect on the way of dying of those that escaped this murder, as well as their descendants, that is to say, ourselves.

In 1915, Freud writes that outside the realm of fiction it has become difficult to find people who know how to die and who even manage to kill someone else in an act of which they recognize themselves as protagonists. ${ }^{36} \mathrm{It}$ is even harder to find such people today. In most cases, a person becomes a criminal to escape unconscious feelings of guilt. To paraphrase Freud, such a person is condemned to kill in order to escape a feeling that could otherwise lead him to self-destruct. The increased unreality of death, of not knowing how to die or kill, is not a sign of personal incapacity or morality. Instead, it characterizes a society that continues to evolve in a world where human beings have become superfluous (Arendt), mere specimens (Adorno), or have been reduced to a potato peel (Antelme).

But could human beings have been reduced to these things without the foundations of our being suffering permanent damage? Can we not understand Adorno's terrible question: After Auschwitz, can we still go on living, do we still have the right?

The shame of the survivor is an affect with terrifying force of contagion; clinical experience has repeatedly shown us its ravaging effects. Speaking about this shame, Primo Levi emphasizes the incurable nature of the offense that has been committed against humanity and says that shame can only spread "like a contagion.... It is an inexhaustible fount of evil." ${ }^{37}$ For Nathalie Zaltzman, this shame is "a blow from which nobody can recover alone. ${ }^{\prime 38}$ It marks a moment of falling outside the human community and requires, in order to be healed, a reinstatement of the pact that seals one's membership in the species. It is transmitted because the survivors cannot but call upon others in trying to reinstate this pact. ${ }^{39}$

35. See Freud, Beyond the Pleasure Principle.

36. See Freud, "Thoughts for the Times on War and Death," 14:145.

37. Primo Levi, The Reawakening: A Liberated Prisoner's Long March Home through East Europe, trans. Stuart Woolf (Boston, 1965), p. 13.

38. Zaltzman, De la guérison psychanalytique, p. 27.

39. On shame, the reader should also refer to the work of Claude Barazer, for example, 
In the course of a psychic or cultural regression, we often see phenomena of depersonalization or disidentification and, more rarely, the feeling of not belonging to the human community. Freud claims that the primal horde is an active principle that continues to work within the psyche and strives for its living reappearance in the world. Should we not consider that in the totalitarian regimes this reappearance was successful far beyond the ambivalent nostalgia for the primal father? Zaltzman's concept of posthistory is very useful here..$^{40}$ Posthistory emerges from a sudden break in the course of history. Under certain conditions, a cultural regression occurs, which reinstates more primitive psychic states, transforming them at the same time. This does not bring about simply a repetition of previously existing forms, but instead produces a neohistory in the form of social neoformations. Totalitarianism would therefore be one of these neoformations. This process also entails a mass employment of the mechanisms of splitting and projection, on both the individual and collective level, leading to, among other things, an experience of desolation, which strikes at the heart of human identification and of our cultural capacities of coexistence.

Kahn's thinking follows in the same direction when she asks whether our ways of thinking about the origins and future of community and culture have changed based on the fact of mass murder, as opposed to the lone murder of the father of the horde. Once the horde had reappeared in modern times, after the totalitarian neoformation, has our thinking about our origins and subjective position retroactively undergone a transformation?

What happens once the primitive horde of Totem and Taboo can no longer serve as the group's only model? ${ }^{21}$ From this horde, humans could extricate themselves by collectively murdering the primal father and then by establishing a foundational pact between the newly differentiated individuals. The mass murder of the totalitarian crowd cannot be overcome by individuation. Each individual participates in it anonymously, impersonally, while its machine annihilates hundreds and thousands of reified individuals at a time, performing its work coldly, methodically, with industrial efficacy. This murder no longer knows who is killing and who or what is being killed. It is performed in cold blood, without excitement,

\footnotetext{
"Hontes sans issues," in Documents et débats, Bulletin de l'Association psychanalytique de France 52 and "Ulysse nu et couvert de boue," Revue française de Psychanalyse 67 (2003): 5.

40. See Zaltzman, L'Esprit du mal.

41. See Freud, Totem and Taboo (1913-14), The Standard Edition of the Complete Psychological Works of Sigmund Freud, 8:vii-162.
} 
without guilt—even without shame. It is only fulfilling a task. Is it still a murder we could appropriate through a foundational narrative, of which we could recognize ourselves as the protagonists? And should we even try?

Adorno points out that the emergence of a new logic of death leaves no place for a hope for the future reconstruction of ideals, and this "signifies that the individual ... in representing the species of man, has lost the autonomy through which he might realize the species." 42 This loss is manifest in the fact that many have described their experience of totalitarianism as "a sense of being not quite there, of not playing along, a feeling as if they were not themselves at all, but a kind of spectator." 43 They were there, but not really present.

Based on these remarks and the frequent recurrence, in my own essay, of words such as unreality, stupor, not belonging, impersonality, anonymous, superfluous, desolation, or waste, I will now put forward a hypothesis I am slightly hesitant to articulate. What we see emerging from all this is a clinical picture reminding us of either Sandor Ferenczi's traumatic neurosis or the so-called new pathologies-borderline personality disorders or borderline states. Is this a false resemblance, or is there a real concordance to be established between these facts?

These psychic structures reveal a fragility of the individual's narcissistic foundations. This is expressed in primitive alterations in the constitution of the ego and of the psychic personality, resulting not in issues of any Oedipal nature or libidinal conflicts but rather pre- or ante-Oedipal problems, as well as problems of identity. These psychic illnesses are dominated by feelings of inexistence, of vagueness or vacuity, of lacking shape and form, of indifferentiation and of lacking real autonomy. Patients describe feelings of existing without really being alive, or of living without really existing; they have doubts about being truly human.

Some of my colleagues think that these pathologies are not really new; what is new is their treatment, made possible by the development and progress of our theory. Others see them as the psychic expression of the present-day forms of discontent in culture, of a crisis caused by the weakening of the paternal function. Fewer are those who attempt to connect these areas of our clinical work to the experience of totalitarian disaster; Kahn's book Faire parler le destin is one such attempt.

Faced with these patients, many of us turn, sometimes with great enthusiasm, to searching for possible etiological causes: real traumatic events in the individual's life or deficiencies in the early family environment.

42. Adorno, Minima Moralia, p. 38.

43. Adorno, Negative Dialectics, p. 363. 
Hence they return to the idea of an essentially external cause and stop questioning what is inherent to the sufferer. I will not try to set up a binary of mutually exclusive endogenous and exogenous causes. My perspective is the old Freudian postulate that any internal compulsion must previously have been external. ${ }^{44}$ Should we not consider the effects of totalitarianism as a form of external compulsion and these pathologies as the result of its interiorization? From this point of view, we are looking at the psychic equivalent of the totalitarian disaster's effects on our culture.

The fracture created by totalitarianism in the history of our world has irreparably damaged the cultural framework, leaving a hole in it, the borders of which we have not yet been fully able to trace. As Eva Weil suggests, the world has entered a period of latency we are still unable to overcome, and this has brought about changes we do not yet understand. ${ }^{45}$ The new pathologies in question could be understood as a sign that something remains active within our psyches: the disaster's destabilizing of the collective foundations that normally serve as a basis for the process of individuation, allowing each of us to become a differentiated and singular being.

Putting an emphasis exclusively on individual trauma or environmental deficiencies spares us the need to consider that the absence or impossibility of a collective representation of the disaster may have had severe psychical repercussions. Can we simply dismiss, without examining it first, the idea of a change to the id that has both modified previously existing mnesic traces and created new ones? If such a hypothesis turns out to be applicable, we would see an effect at the level of the process of identification $^{46}$ because the shared foundations of community would have been modified both internally and externally, yet imperceptibly to those who carry them within. This would be a consequence of the fact that what was seen in the death camps could not have been translated and cannot constitute a narrative able to contain the disaster. The destabilization of ideals then arguably forces each individual to constitute him or herself also based on the encounter with this hole in the fabric of the collective. He or she has to hold onto the human community after having been confronted with the gaping emptiness left behind by totalitarian annihilation, a void the individual already carries within. This void is the result of the experience of desolation and a source of profound solitude, which endlessly refers each

\footnotetext{
44. See Freud, "Thoughts for the Times on War and Death," 14:281.

45. See Weil, "Silence et latence," Revue Française de Psychanalyse 64, no. 1 (2000): 169-79.

46. As we know, in Freud's view, each individual's process of identification must either rely on objects in his or her environment or draw on the traces of ancestor experience preserved in the id.
} 
individual back to himself as the only purpose and end. Perhaps more so than before, each individual today is asked to justify his existence-with the risk of mistaking oneself for a monad.

Unless we pay sufficient attention to the fact that the constitution of psychical personality depends not only on the state of the world around us but also on the traces of previous worlds that we carry within ourselves, we will make the mistake of grossly overpersonalizing individual stories. The dimension of heroism present in the accounts of clinical experiences with these patients would thus be a sign of autocratic retrenchment.

My entire argument is haunted by a certain fear. Do we not overestimate psychical indestructibility? It is in fact only the mnesic traces that are indestructible; on the contrary, psychic processes and their results are not. The psyche can be affected by the destructiveness of the world, as well as by its own destructive tendencies. Its conditions of possibility, including civilization itself, can, too, be destroyed or altered. I am afraid that we are even guiltier of this overestimation when we refuse to consider the seemingly improbable elements of our theory. When Adorno writes: "In psychoanalysis nothing is true except the exaggerations," ${ }^{47}$ he is able to take them more seriously than we sometimes do.

Is it not time we took them seriously? Do they not contain material that could help us grasp the effects of these disasters? Perhaps psychoanalytic theory has at its disposal resources we have not yet fully understood but that could help us face the real of the world while making a greater contribution to the work of culture. By assuming this perspective, we will inscribe ourselves in the historical and cultural chain of which each individual is only a link. Throughout history, we have seen man's desire to break off this chain and become his own purpose; however, the totalitarian attack on it was unprecedentedly ferocious. We still have hope, although as Walter Benjamin writes: "Only for the sake of the hopeless ones have we been given hope." ${ }^{8}$ We hope that the chain has not been broken and that it continues to produce, from time to time, the tiny variations that constitute the eternal drift of not continents but life itself. We are only a transient expression of this life, which culture endeavors to preserve beyond our individual death.

Although I do not believe that I can quite avoid the misunderstandings this text will undoubtedly provoke, I will nonetheless try to clarify a few points. The fact that the word Shoah does not appear in this text is a

47. Adorno, Minima Moralia, p. 49.

48. Walter Benjamin, "Goethe's Elective Affinities," trans. Stanley Corngold, Walter Benjamin: Selected Writings, trans. Edmund Jephcott, et al., ed. Michael W. Jennings, Howard Eiland, and Gary Smith, 4 vols. (1924-25; Cambridge, Mass., 2005), 1:356. 
deliberate and carefully made choice. What I call the disaster, or catastrophe, or cataclysm obviously includes the final solution, the project of exterminating the entire Jewish people, that is, all Jews. The final solution is of course one of the key principles of Nazi totalitarianism (and this is explicitly stated in Mein Kampf); however, in the Nazi ideology, the word Jew represents a lot more than just the Jewish people. As a number of authors have pointed out, the hatred of the Jew is the hatred of culture, the hatred of incompleteness and of human limitations. Freud writes that in the world of the Aryan ideal, the Jew plays the role of an agent of economic discharge. In Moses and Monotheism, he claims that the hatred of Jews stems from the fact that the father's murder at the origins of Christianity has not been fully recognized and has led to a travesty of attributing the responsibility for it primarily to the Jewish people, who are now accused of having murdered the Christian God. ${ }^{49}$ In this perspective, the hatred of Jews translates a disavowal of the real foundations of monotheism. Kahn suggests that after mass exterminations we need another measure to think about horror:

It is not because the guilt that has been transmitted without memory, generation after generation, is finally monstrously expiated through the anti-Semitic hatred of that age, but because the elimination of Jews suddenly shows the West how relentlessly it hates, also without remembering it, something within itself: something internal rather than external, the very core of its own civilization, its cultural origin and the genealogy of its thought. [F, p. 228]

The totalitarian regime is a realization of this hatred; what I call the disaster, catastrophe, or cataclysm refers to these actions and their effects. I have used the word disaster without consciously thinking of Maurice Blanchot's The Writing of the Disaster - which is why I make no direct reference to it; I have not sufficiently examined my debt to a book that nonetheless had a great effect on me and was an important event in my life..$^{50}$ At the same time, this essay obviously deals with some of the paradoxes discussed in Blanchot's The Infinite Conversation, where he reflects on Antelme's The Human Race: "Man is the indestructible that can be destroyed." ${ }^{1}$ Isn't one of thought's present tasks to think about, on the one hand, this indestruc-

49. See Freud, Moses and Monotheism (1939), The Standard Edition of the Complete Psychological Works of Sigmund Freud, 23:90.

50. See Maurice Blanchot, The Writing of the Disaster, trans. Ann Smock (Lincoln, Nebr., 1988).

51. Blanchot, The Infinite Conversation, trans. Susan Hanson (Minneapolis, 1993), p. 130. See Antelme, The Human Race, trans. Haight and Annie Mahler (Evanston, Ill., 1998). 
tibility of our species, our determination to persevere in our indivisible unity and overcome barbarism (Antelme) and, on the other, about the individual's loss of capacity to realize the species (Adorno)? After totalitarianism, it is possible that the culture's discontents have become intensified to such a degree that the word has become only a euphemism, preventing us from seeing that we have now moved beyond discontent and are thus forced to think in the tension between the above two propositions while having to bear a deep and fundamental disquietude. 